\title{
Hubungan Antara Coping Terkait Stres Sekolah Dan Persepsi Keterlibatan Orangtua Pada Remaja
}

\section{(Relationship beetwen Coping with School-Related Stress and Perception of Parental Involvement among Adolescents)}

\author{
NAMIRA INSYIRANDA ${ }^{1}$, AIRIN YUSTIKARINI SALEH ${ }^{2}$
}

Fakultas Psikologi, Universitas Indonesia

E-mail: insyiranda@gmail.com

\begin{abstract}
Applying functional coping when dealing with school-related problems is very important that can be benefical to make a good academic performance at the school. There are several factors that can affect the use of coping in adolescents. Parental involvement was assumed can predict the use of coping in adolescents. The aim of this study is to examine the relationship between parental involvement that perceived by students and coping with school-related stress in adolescence. Participants of this study was 405 adolescents in third grade of high school from eight different schools. Perceived parental involvement was measured in two version for father and mother, using Reported Father Involvement Scale (Finley \& Schwartz, 2004) and Reported Mother Involvement Scale (Finley, Mira, \& Schwartz, 2008). Coping with school-related stress was measured by Coping Accross Situational Questionnaire-Revised (Barnes, 2011). The result showed that there are significant relationship between two types of coping style, that were active coping and internal coping with both perceived father involement and perceived mother involvement.
\end{abstract}

Keywords: Stress, Active Coping, Internal Coping, Parental Involvement, Adolescents

\section{PENDAHULUAN}

Remaja merupakan individu yang paling rentan mengalami stres akibat sekolah, disebabkan pada masa ini terjadi banyak perubahan dalam kehidupan mereka, meliputi meningkatnya tekanan akademis, dorongan untuk menjadi mandiri, hubungan dekat dengan teman sebaya, dan kematangan fisik (Camara, Bacigalupe, \& Padilla, 2014). Masalah berkaitan dengan sekolah (schoolrelated stressor) seringkali menjadi sumber tekanan atau stress yang paling umum ditemukan pada individu usia remaja (LaRue \& Herrman, 2008). School-related stress merupakan berbagai tekanan berkaitan dengan kondisi di sekolah yang seringkali dirasakan sebagai keadaan yang stresful bagi remaja
(LaRue \& Herrman, 2008). Hal-hal berkaitan dengan sekolah seperti kenaikan kelas, mempertahankan nilai bagus, kelulusan dan persiapan menuju perkuliahan, merupakan berbagai kekhawatiran yang ditandai sebagai stressor atau sumber stres oleh para siswa (LaRue \& Herrman, 2008).

Berdasarkan survei yang dilakukan oleh APA pada tahun 2013 ditemukan bahwa sebanyak $80 \%$ remaja menyatakan sekolah sebagai sumber stres yang paling signifikan dirasakan dan berasosiasi dengan perilaku yang kurang baik, seperti menolak tanggungjawab di sekolah maupun di rumah, menunda tugas (prokrastinasi), bertengkar dengan teman, dan gangguan dalam menjalin hubungan sosial dengan keluarga ataupun 
teman (Shankar \& Park, 2016). Di Indonesia, melalui penelitian Taufik dan Ifdil (2013) pada 319 siswa SMA di kota Padang ditemukan sebanyak $71,8 \%$ siswa mengalami stres akademik tingkat sedang dan $13 \%$ mengalami stres akademik tingkat tinggi. Mekanisme penanganan stres yang belum matang serta kurangnya pengalaman remaja dalam menghadapi situasi yang stresful, dapat membuat stres yang dirasakan oleh remaja semakin tinggi (Herrman, 2005 dalam LaRue \& Herrman, 2008).

Paparan keadaan stress dalam jangka waktu yang lama dapat menimbulkan berbagai macam gangguan fisik dan psikologis (Goodman et al, 2005 dalam LaRue \& Herrman, 2008). Siswa akan memiliki hambatan yang signifikan dalam proses belajar meliputi atensi, memori, serta kemampuan untuk menentukan apa yang penting dan tidak penting untuk diperhatikan ketika merasakan stres yang berlebihan (Murray, Low, Hollis, Cross dan Davis, 2007 dalam Frank, Bose, \& Schrobenhauser-Clonan 2014). Oleh karena itu, dibutuhkan penerapan strategi penanganan stres yang tepat untuk mencegah dampak buruk dari keadaan stres tersebut atau biasa disebut sebagai coping.

Coping berfokus pada usaha individu untuk mengatasi kondisi stres yang berkaitan dengan situasi sehari-hari yang relevan dengan kehidupan remaja, salah satunya sekolah (Seiffge-Krenke \& Shulman, 1990). Coping yang dilakukan oleh siswa akan memengaruhi kesehatan mental dan fisik siswa yang kemudian akan menentukan bagaimana siswa berpikir, merasakan, dan bertindak (Frank, Bose, \& Schrobenhauser-Clonan 2014). Terdapat tiga gaya coping atau coping style yang biasa ditampilkan oleh remaja saat menghadapi masalah dalam tugas perkembangan mereka (Seiffge-Krenke \& Shulman, 1990). Pertama, active coping meliputi penanganan masalah secara aktif, seperti mencari informasi dan meminta nasihat, mencari bantuan emosional dari orangtua, teman, atau pusat konseling untuk menyelesaikan masalah yang dihadapi, tergolong dalam style fungsional, kedua internal coping yang menekankan kepada evaluasi remaja terhadap situasi yang mereka hadapi dan pencarian kompromi, penyelesaian masalah secara mandiri yang juga tergolong dalam style fungsional, serta terakhir withdrawal yang dinilai sebagai style disfungsional yaitu menekankan pada sikap menarik diri saat menghadapi masalah.

Saat menghadapi sekolah, penelitian menunjukkan bahwa remaja lebih menerapkan coping yang bersifat fungsional, yaitu active dan internal dibandingkan dengan withdrawal (Seiffge-Krenke, 1990; Gelhaar, SeiffgeKrenke, Borge, Cicognani, Loncaric, Macek, \& Metzke, 2007; Seiffge-Krenke, Aunola, \& Nurmi, 2009). Selain itu, ditemukan juga bahwa withdrawal memiliki hubungan yang negatif dengan hubungan antara anak dan orangtua, maka pada penelitian ini coping style yang diteliti hanya yang bersifat fungsional, yaitu active coping dan internal coping dan tidak meneliti withdrawal coping.

Coping style yang dilakukan oleh remaja berkaitan dengan permasalahan sekolah, dinyatakan bergantung baik secara langsung maupun tidak langsung pada beberapa faktor, salah satunya yaitu situasi keluarga, khususnya hubungan anak dengan orangtua (Wrzesniewski \& Chylinska, 2007). 
Hubungan yang suportif berasal dari orangtua menjadi sumber daya bagi anak untuk melakukan coping terhadap stres (Camara, Bacigalupe, dan Padilla, 2014). Bentuk peranan orangtua dapat dinilai secara berbedabeda, salah satunya ialah melalui keterlibatan orangtua yang dipersepsikan oleh anak itu sendiri.

Keterlibatan orangtua menunjukkan seberapa besar orangtua ikut berpartisipasi dalam berbagai aspek kehidupan anak mereka (Finley, Mira, \& Schwartz, 2008). Aspek kehidupan anak tersebut dapat meliputi berbagai aspek perkembangan, seperti perkembangan intelektual, emosi, sosial, moral/etika, dan lain-lain. Finley dan Schwartz (2004) mengelompokkan dimensi keterlibatan orangtua terhadap aspek perkembangan anak menjadi tiga, yaitu instrumental, ekspresif, dan mentoring/advising. Anak kemudian akan mempersepsikan sejauh mana orangtua mereka terlibat dalam masing-masing dimensi tersebut (Finley \& Schwartz, 2004).

Dalam prosesnya, terdapat perbedaan antara keterlibatan seorang ayah dan seorang ibu yang dipersepsikan oleh anak (Finley, Mira, \& Schwartz, 2008). Ayah dinilai lebih terlibat dalam pemenuhan hal-hal yang bersifat instrumental, seperti memberi nafkah dan menerapkan disiplin dalam proses pembelajaran dan dalam aspek lainnya, mendorong anak untuk bertanggung jawab dan mandiri, dan pengembangan moral/etika (Finley, Mira, \& Schwartz, 2008), sehingga dapat mendorong coping style yang lebih internal pada seorang anak, sedangkan ibu dinilai lebih terlibat dalam pemenuhan hal-hal yang bersifat ekspresif (Finley, Mira, \& Schwartz, 2008) dan mentoring/advising (Han
\& Jun, 2013), seperti pengasuhan, pertemanan, bantuan emosional, berbagi kegiatan yang bersifat rekreasi, pemberian nasihat, dan bimbingan/pengajaran (Finley, Mira, \& Schwartz, 2008), sehingga dapat mendorong coping style yang lebih aktif pada seorang anak.

Beberapa hasil penelitian menunjukkan bahwa terdapat hubungan yang positif antara keterlibatan orangtua dengan performa akdemik dan perilaku sehat pada siswa. Diantaranya penelitian Wong (2008) menemukan bahwa keterlibatan orangtua yang dipersepsikan oleh remaja berkorelasi secara positif dengan self-regulation dan performa akademik pada remaja. Penelitian lain oleh Wang dan Sheikh-Khalil (2014) menunjukkan hasil bahwa terdapat hubungan yang negatif antara keterlibatan orangtua di sekolah (school-based involvement) dan sosialisasi akademik dengan kondisi depresi pada remaja, yang artinya ketika tingkat keterlibatan orangtua di sekolah dan sosialisasi akademik orangtua terhadap anak tinggi, maka sebaliknya tingkat depresi pada anak menjadi rendah. Keterlibatan orangtua juga dapat membantu remaja dalam menentukan targettarget, memotivasi, serta menyediakan sumber daya bagi remaja untuk menghadapi berbagai peristiwa sehari-hari yang mungkin menjadi sumber tekanan, meliputi tantangan akademik, sosial, dan personal remaja itu sendiri (Gonzales-DeHass, Willems, \& Holbein, 2005).

Namun demikian, masih terdapat perbedaan hasil mengenai hubungan antara keterlibatan orangtua dengan penggunaan pada masing-masing coping style anak. SeiffgeKrenke dan Pakalniskene (2011) menjelaskan 
bahwa terdapat perbedaan pola pengasuhan antara ayah dan ibu yang kemudian memengaruhi perkembangan coping pada anak. Ayah cenderung mendorong anak mereka untuk bisa mandiri sesegera mungkin, sehingga anak didorong untuk menyelesaikan masalah secara mandiri dengan mengandalkan diri mereka sendiri yang mana hal tersebut merupakan bentuk internal coping, sedangkan ibu sebaliknya lebih banyak terlibat dalam aspek perkembangan anak yang mendorong anak untuk menyelesaikan masalah secara aktif (Seiffge-Krenke \& Pakalniskene, 2011).

Selain itu, dari hasil penelitian sebelumnya juga menyatakan bahwa terdapat perbedaan coping style yang diterapkan oleh anak, bergantung pada konteks budaya tempat anak tersebut tinggal (Persike \& SeiffgeKrenke, 2012). Pada negara tertentu anak didorong untuk menyelesaikan masalah dengan bergantung atau meminta bantuan kepada keluarga (Persike \& Seiffge-Krenke, 2012) yang mana cara tersebut identik dengan active coping, sedangkan pada negara yang lainnya anak didorong untuk mampu bekerja secara mandiri yang mana cara tersebut identik dengan internal coping.

Hal tersebut menunjukkan adanya hasil yang berbeda-beda mengenai coping style yang biasa diterapkan remaja di setiap negara sesuai dengan nilai dan budaya yang ada pada negara tersebut. Oleh karena itu, peneliti tertarik untuk melakukan penelitian di negara Indonesia yang tentunya memiliki karakteristik yang berbeda dengan negara lain pada penelitian-penelitian sebelumnya. Selain itu, berdasarkan adanya perbedaan hasil mengenai hubungan antara keterlibatan orangtua dengan masing-masing coping style, maka pada penelitian ini bertujuan untuk melihat apakah terdapat hubungan antara coping, yaitu active coping dan internal coping dengan persepsi keterlibatan orangtua (ayah dan ibu).

\section{METODE}

Partisipan Penelitian. Partisipan yang terlibat dalam penelitian ini merupakan 405 orang siswa/i kelas tiga SMA yang sekolah di wilayah Jabodetabek. Pada penelitian ini pengambilan sampel dilakukan dengan teknik non-probability sampling, yaitu convenience sampling berdasarkan kesediaan dan keinginan mereka dalam memberi respon (Gravetter \& Forzano, 2012). Siswa kelas tiga SMA dipilih karena usia SMA tergolong usia remaja akhir yang lebih rentan mengalami stres sebab individu menjadi lebih sensitif dengan keadaan lingkungan di sekitarnya, berusaha untuk memenuhi berbagai tuntutan sesuai dengan harapan diri dan orang lain (Lin \& Yussof, 2013). Pada tingkatan ini stres yang dialami oleh siswa diasumsikan lebih tinggi karena siswa menghadapi tuntutan yang lebih kompleks dibanding tingkatan-tingkatan sebelumnya, diantaranya ialah persiapan ujian akhir nasional dan persiapan memasuki perguruan tinggi yang akan mengarahkan masa depan mereka.

Prosedur Penelitian. Pada penelitian ini data dikumpulkan secara langsung dengan memberikan kuesioner cetak pada partisipan yang berisi alat ukur kedua variabel, yaitu coping dan persepsi keterlibatan orangtua. Partisipan diminta untuk mengisi kuesioner saat itu juga di waktu dan tempat yang sama 
saat kuesioner dibagikan.

Instrumen Penelitian. Pengukuran coping with school-related stress dilakukan dengan menggunakan Coping Across Situations Questionnaire Revised (CASQ-R) oleh Barnes (2011). CASQ-R merupakan hasil revisi dari CASQ yang dikembangan oleh Seiffge-Krenke (1995, dalam Barnes 2011). CASQ-R terdiri atas 21 item yang mencakup tiga coping style, yaitu active, internal, dan withdrawal. Namun, pada penelitian ini item-item yang akan digunakan hanya item-item yang tergolong jenis active coping dan internal coping, yaitu berjumlah 14 item.

Alat ukur ini dapat digunakan untuk mengukur coping pada delapan domain yang mungkin menjadi sumber stres pada remaja, yaitu sekolah, orangtua, teman sebaya, pasangan romantis, waktu luang, diri sendiri, pekerjaan, dan masa depan (Seiffge-Krenke \& Shulman, 1990). Pada penelitian ini, domain yang akan diteliti hanya berkaitan dengan sekolah. Partisipan diminta untuk memilih skala 1-5 yang menunjukkan seberapa sering (1=tidak pernah, 2=jarang, 3=kadang-kadang, 4=sering, dan 5=selalu) mereka melakukan gaya coping tertentu dalam menghadapi masalah sekolah tertentu dalam seminggu.

Pengukuran persepsi keterlibatan orangtua dilakukan dengan dua variasi pengukuran, yaitu mengukur persepsi keterlibatan ayah dan mengukur persepsi keterlibatan ibu. Persepsi keterlibatan ayah diukur dengan menggunakan alat ukur Reported Father Involvement Scale atau RFIS (Finley \& Schwartz, 2004) dan persepsi keterlibatan ibu diukur dengan Reported Mother Involvement Scale atau RMIS (Finely,
Mira, \& Schwartz, 2008) yang telah diadaptasi dan diterjemahkan oleh Miranti Anindya Ayu pada tahun 2014 dan digunakan kembali pada penelitian Affiani (2016). RFIS dan RMIS masing-masing terdiri atas 20 item yang mencakup tiga dimensi keterlibatan orangtua, yaitu ekspresif, instrumental, dan mentoring/advising (Finley \& Schwartz, 2004). Alat ukur ini digunakan untuk mengukur keterlibatan orangtua pada 20 area perkembangan anak yang memungkinkan orangtua untuk terlibat atau tidak terlibat, yaitu pengembangan rasa tanggung jawab, pendisiplinan, pengembangan moral/etika, perlindungan, memberi nafkah, pengembangan karir, kemandirian, sekolah/tugas sekolah, pengembangan aspek fisik, pertemanan, rekreasi/bermain, kegiatan bersama, emosi, pengasuhan, spiritual, serta pengembangan kompetensi, bimbingan/pengajaran, memberi nasihat, dan perkembangan intelektual.

Perhitungan skor dilakukan dengan cara menjumlahkan item-item yang ada pada masing-masing alat ukur RFIS dan RMIS. Skala 1 sampai 5 yang dipilih oleh partisipan menunjukkan nilai untuk tiap-tiap item. Partisipan yang memilih respon "tidak pernah terlibat" akan diberi skor 1, "jarang terlibat" diberi skor 2, "kadang-kadang terlibat" diberi skor 3, "sering terlibat" diberi skor 4, dan "selalu terlibat" diberi skor 5. Rentang skor yang diperoleh untuk masing-masing alat ukur (RFIS dan RMIS) ialah 20-100. Semakin tinggi skor yang diperoleh menunjukkan semakin tinggi pula persepsi partisipan terhadap keterlibatan orangtua mereka.

Analisis terhadap variabel yang diteliti dengan menggunakan dua teknik analisis. Pertama, yaitu analisis deskriptif yang 
dilakukan untuk untuk melihat gambaran secara umum dari karakteristik partisipan, meliputi usia dan jenis kelamin, serta rata-rata, skor minimum/maksimum, dan standar deviasi dari masing-masing variabel yang diteliti. Kedua, yaitu analisis korelasi dengan teknik perason correlation yang digunakan untuk melihat derajat dan arah hubungan linear antar dua variabel (Gravetter \& Wallnau, 2013). Pada penelitian ini, variabel yang akan dikorelasikan adalah coping with schoolrelated stress yang terbagi menjadi active coping dan internal coping dengan perceived parental involvement yang terdiri dari perceived father involvement dan perceived mother involvement.

\section{HASIL}

Peneliti melakukan analisis deskriptif dengan menghitung nilai rata-rata (mean), skor minimum, skor maksimum, dan standar deviasi yang diperoleh dari data untuk tiap subskala coping, yaitu active coping dan internal coping yang dapat dilihat pada tabel 4.1. Berdasarkan hasil perhitungan diperoleh nilai rata-rata yang lebih besar pada coping style internal dibandingkan dengan coping style active. Hal tersebut menunjukkan bahwa sebagian besar partisipan lebih menerapkan internal coping saat menghadapi permasalahan berkaitan sekolah, yaitu dengan mengandalkan diri sendiri meliputi berpikir tentang berbagai solusi yang dapat dilakukan, mengenali keterbatasan yang dimiliki, dan kemauan untuk berdamai dengan masalah (SeiffgeKrenke \& Nurmi, 2009).
Tabel 4.1 Gambaran Skor Coping With School-Related Stress

\begin{tabular}{cccccc}
\hline $\begin{array}{c}\text { Jenis } \\
\text { Coping }\end{array}$ & $\begin{array}{c}\text { Jumlah } \\
\text { Item }\end{array}$ & Mean & $\begin{array}{c}\text { Std. } \\
\text { Dev. }\end{array}$ & $\begin{array}{c}\text { Skor } \\
\text { Min. }\end{array}$ & $\begin{array}{c}\text { Skor } \\
\text { Max. }\end{array}$ \\
\hline $\begin{array}{c}\text { Active } \\
\text { Coping }\end{array}$ & 7 & 3,20 & 0,679 & 1 & 5 \\
$\begin{array}{c}\text { Internal } \\
\text { Coping }\end{array}$ & 7 & 3,81 & 0.533 & 1 & 5 \\
\hline
\end{tabular}

Hal yang sama juga dilakukan untuk melihat gambaran skor pada variabel keterlibatan orangtua, baik ayah maupun ibu. Berdasarkan tabel 4.2 diperoleh nilai rata-rata persepsi keterlibatan ibu yang lebih tinggi, yaitu sebesar 4,42 dibandingkan dengan nilai rata-rata persepsi keterlibatan ayah, yaitu sebesar 4,12. Berdasarkan skala 1-5 yang digunakan pada alat ukur diketahui bahwa sebagian besar partisipan menjawab "sering" dalam mempersepsikan keterlibatan orangtua mereka, baik ayah ataupun ibu. Hal tersebut berarti bahwa sebagian besar partisipan dalam penelitian ini menilai ayah dan ibu mereka sering terlibat dalam proses pengasuhan di masa lalu.

\section{Tabel 4.2 Gambaran Skor Persepsi}

Keterlibatan Ibu dan Ayah

\begin{tabular}{cccccc}
\hline Variabel & $\begin{array}{c}\text { Jumlah } \\
\text { Item }\end{array}$ & Mean & $\begin{array}{c}\text { Std. } \\
\text { Dev. }\end{array}$ & $\begin{array}{c}\text { Skor } \\
\text { Min. }\end{array}$ & $\begin{array}{c}\text { Skor } \\
\text { Max. }\end{array}$ \\
\hline $\begin{array}{c}\text { Persepsi } \\
\text { Keterlibatan } \\
\text { Ibu }\end{array}$ & 20 & 4,42 & 0,615 & 1 & 20 \\
$\begin{array}{c}\text { Persepsi } \\
\text { Keterlibatan } \\
\text { Ayah }\end{array}$ & 20 & 4,12 & 0,798 & 1 & 20 \\
\hline
\end{tabular}


Hasil utama dari penelitian ini ialah melihat hubungan dari dua jenis coping, yaitu active coping dan internal coping dengan persepsi keterlibatan orangtua yang terbagi menjadi persepsi keterlibatan ayah dan persepsi keterlibatan ibu. Berdasarkan pengukuran yang dilakukan perhitungan akan dibagi menjadi empat, yaitu hubungan antara jenis active coping dan persepsi keterlibatan ayah, hubungan antara jenis active coping dan persepsi keterlibatan ayah, hubungan antara jenis internal coping dan persepsi keterlibatan ibu, serta hubungan antara jenis internal coping dan persepsi keterlibatan ibu.

\section{Tabel 4.3 Hasil Analisis Korelasi Coping}

With School-Related Stress dan Persepsi Keterlibatan Orangtua

\begin{tabular}{cccc}
\hline & & $\begin{array}{c}\text { Active } \\
\text { Coping }\end{array}$ & $\begin{array}{c}\text { Internal } \\
\text { Coping }\end{array}$ \\
\hline Persepsi & $\mathbf{r}$ & $0,272^{* *}$ & $0,139^{* *}$ \\
Keterlibatan & $\boldsymbol{p}$ & 0,000 & 0,005 \\
Ayah & & & \\
Persepsi & $\mathbf{r}$ & $0,287^{* *}$ & $0,137^{* *}$ \\
Keterlibatan & $\boldsymbol{p}$ & 0,000 & 0,005 \\
Ibu & & & \\
\hline
\end{tabular}

\section{Nilai korelasi yang positif} menunjukkan hubungan yang positif antara kedua variabel, yaitu active coping dan internal coping dengan persepsi keterlibatan ayah dan persepsi keterlibatan ibu, artinya semakin tinggi skor active coping dan internal coping maka semakin tinggi pula skor persepsi keterlibatan ayah dan skor persepsi keterlibatan ibu. Hal tersebut berarti bahwa ketika penerapan active coping dan internal coping pada anak meningkat, maka persepsi anak terhadap keterlibatan ayah dan keterlibatan ibu mereka di masa lalu dalam proses pengasuhan juga akan meningkat.

\section{DISKUSI}

Diketahui bahwa terdapat hubungan antara active coping dan persepsi keterlibatan ayah, active coping dan persepsi keterlibatan ibu, internal coping dan persepsi keterlibatan ayah, serta internal coping dan persepsi keterlibatan ibu. Berdasarkan hal tersebut dapat diartikan bahwa kedua coping style (active coping dan internal coping) dapat dijelaskan oleh persepsi keterlibatan orangtua (ayah dan ibu). Hasil tersebut sesuai dengan yang dijelaskan oleh Wrzesniewski dan Chylinska (2007) bahwa coping terkait stres di sekolah juga dinyatakan bergantung baik secara langsung maupun tidak langsung pada beberapa faktor, salah satunya yaitu situasi keluarga, khususnya hubungan anak dengan orangtua dan keadaan ekonomi keluarga. Hubungan yang suportif berasal dari orangtua, saudara, dan orang dewasa lainnya menjadi sumber daya untuk melakukan coping terhadap stres (Camara, Bacigalupe, dan Padilla, 2014). Iklim keluarga yang positif akan menjamin respon coping remaja yang bersifat adaptif (Holmbeck dkk., 1995 dalam Seiffge-Krenke \& Pakalniskiene, 2010).

Keterlibatan orangtua yang dipersepsikan oleh anak menjadi salah satu bentuk hal yang dapat menjamin kualitas hubungan antara orangtua dan anak tersebut. Dengan adanya keterlibatan orangtua dalam proses pengasuhan, anak akan merasa mendapatkan dukungan serta sumber daya untuk dapat melakukan coping yang baik 
ketika menghadapi masalah sekolah. Orangtua yang terlibat juga akan memunculkan perasaan positif pada diri anak bahwa mereka merasa terkoneksi dan aman dalam pengawasan orangtua mereka (Gonzales-DeHass, Willems, \& Holbein, 2005), sehingga saat menghadapi masalah sekolah akan sangat mungkin bagi mereka untuk lebih terbuka dengan orangtua mereka agar memperoleh bantuan dalam menyelesaikan masalah.

Selain itu, keterlibatan orangtua juga berperan sebagai agen sosialisasi mengenai pentingnya pendidikan kepada anak, melalui keterlibatannya yang dirasakan oleh anak akan memunculkan motivasi dalam diri anak dalam melakukan proses pembelajaran (GonzalesDeHass, Willems, \& Holbein, 2005). Keterlibatan orangtua sangat membantu anak dan remaja dalam proses pembelajaran dan keberhasilan akademis mereka (GonzalezDeHass, Willems, \& Holbein, 2005). Anak akan merasa termotivasi ketika menyaksikan orangtua mereka memiliki keterlibatan aktif tentang sekolah mereka (Gonzalez-DeHass, Willems, \& Holbein, 2005).

Ketertarikan dan antusiasme orangtua yang tampil dalam keterlibatan mereka dalam proses pembelajaran anak-anak, mereka akan menyediakan support system bagi anak yang dapat meningkatkan pembelajaran akademis anak serta menanamkan pentingnya nilai pendidikan pada anak (Aimes, 1995 dalam Gonzalez-DeHass, Willems, \& Holbein, 2005). Ketika anak menginternalisasi pentingnya nilai pendidikan dari orangtua mereka dan memiliki motivasi untuk melakukan pembelajaran, mereka akan memiliki pengendalian diri yang lebih baik saat menghadapi masalah sekolah, sehingga saat menghadapi masalah-masalah tersebut mereka akan memilih cara-cara yang baik yang mengarahkan pada penyelesaian masalah itu sendiri.

Berdasarkan hasil analisis diketahui juga bahwa diperoleh hasil korelasi yang lebih tinggi antara keterlibatan orangtua (ayah dan ibu) dengan active coping. Hal tersebut menunjukkan bahwa ketika orangtua terlibat secara aktif maka anak juga cenderung menyelesaikan masalah secara aktif dengan meminta bantuan dan dukungan dari orangtua mereka. Seperti yang dijelaskan oleh SeiffgeKrenke dan Pakalniskiene (2010) ketika anak merasakan kedekatan secara emosional dengan orangtua mereka anak akan merasa bahwa mereka dapat menyampaikan berbagai isu permasalahan kepada kedua orangtua mereka. Keterlibatan orangtua yang lebih tinggi yang dipersepsikan oleh anak akan mendorong anak untuk menyelesaikan masalah secara aktif dengan lebih terbuka dalam meminta bantuan serta dukungan dari orangtua mereka. Sebaliknya, ketika anak mempersepsikan keterlibatan orangtua mereka lebih rendah, anak cenderung menyelesaikan masalah dengan lebih mengandalkan diri mereka sendiri. Oleh karena itu, nilai korelasi antara persepsi keterlibatan orangtua dan active coping lebih tinggi dibanding nilai korelasi antara persepsi keterlibatan orangtua dan internal coping.

Hasil penelitian juga menunjukkan bahwa skor rata-rata internal coping partisipan lebih tinggi dibandingkan dengan skor ratarata active coping. Skor rata-rata internal coping yang lebih tinggi dibandingkan dengan active coping juga menunjukkan bahwa partisipan lebih mengandalkan diri mereka 
sendiri ketika menghadapi masalah sekolah. Hal ini sesuai dengan beberapa penelitian yang menyatakan bahwa individu pada usia remaja memiliki dorongan yang kuat untuk menjadi lebih mandiri dan tidak lagi bergantung pada kedua orangtua (Somerville, Jones, \& Casey, 2010; Verboom, Verhulst, Sijtsema, \& Pennix, 2014). Pada usia remaja, individu mulai melakukan pencarian otonomi yang terwujud salah satunya dalam proses pengambilan keputusan secara mandiri (Seiffge-Krenke \& Pakalniskiene, 2010). Pada usia remaja ini, pengawasan orangtua lebih berkurang dan anak memiliki dorongan untuk melakukan berbagai hal secara bebas (Seiffge-Krenke \& Pakalniskiene, 2010). Namun demikian, orangtua dapat berperan dalam proses negosiasi dengan anak dalam membuat keputusan. Oleh karena itu pada penelitian ini juga diketahui adanya hubungan antara keterlibatan orangtua dengan internal coping.

\section{SIMPULAN}

Dengan demikian dapat disimpulkan bahwa terdapat hubungan antara active coping dan persepsi keterlibatan ayah, terdapat hubungan antara internal coping dan persepsi keterlibatan ayah, terdapat hubungan active coping dan persepsi keterlibatan ibu, serta terdapat hubungan antara internal coping dan persepsi keterlibatan ibu. Selain itu, melalui analisis gambaran skor coping with schoolrelated stress diketahui bahwa skor rata-rata jenis internal coping lebih tinggi daripada jenis active coping. Hal ini menunjukkan bahwa partisipan lebih banyak menggunakan jenis internal coping dalam menghadapi stress berkaitan dengan sekolah. Sedangkan pada gambaran skor persepsi keterlibatan orangtua, diketahui bahwa skor rata-rata persepsi keterlibatan ibu lebih tinggi daripada persepsi keterlibatan ayah. Hal ini menunjukkan bahwa partisipan menilai ibu lebih terlibat dalam proses penngasuhan di masa lalu dibandingkan ayah mereka.

\section{SARAN}

Dalam melakukan penelitian ini peneliti menyadari masih terdapat keterbatasan yang disarankan diperbaiki pada penelitian selanjutnya. Pertama, pada penelitian ini tidak diketahui bentuk permasalahan sekolah apa saja dan yang paling dipersepsikan sebagai sumber stress terkait sekolah oleh partisipan. Penelitian ini juga tidak mengukur tingkatan stress yang dirasakan oleh partisipan terkait sekolah. Hal ini tentu seharusnya penting untuk dilakukan agar sekolah ataupun orangtua dapat melakukan intervensi terkait stres yang dirasakan oleh siswa berkaitan dengan permasalahan sekolah.

Selanjutnya, pada penelitian ini juga diperoleh hasil yang kurang baik terkait validitas pada beberapa item alat ukur serta nilai reliabilitas yang relatif kecil. Hal ini mungkin dikarenakan saat melakukan uji coba alat ukur, kriteria sampel yang digunakan kurang tepat sasaran. Saat uji coba, sampel diambil secara acak, sedangkan pada penelitian sebelumnya alat ukur dicobakan pada remaja yang dirujuk secara langsung oleh klinik-klinik kesehatan yang menunjukkan bahwa remaja tersebut diketahui memiliki tingkat stres yang tinggi dan remaja dengan tingkat stres normal, sehingga alat ukur dapat 
membedakan kedua jenis individu tersebut dan diperoleh nilai yang baik untuk reliabilitas dan validitas dari alat ukur tersebut. Oleh karena itu, disarankan pada penelitian selanjutnya untuk tidak hanya berpatokan pada jumlah sampel saat uji coba, melainkan juga memastikan agar sampel saat melakukan uji coba memiliki kriteria yang tepat, hal tersebut dapat dilakukan dengan meminta bantuan ahli atau orang-orang terdekat individu yang akan dijadikan sampel penelitian saat uji coba.

Kemudian, penelitian ini juga tidak meneliti faktor-faktor lain yang juga mungkin memiliki hubungan dengan coping style pada siswa. Pada penelitian sebelumnya dikatakan bahwa aspek lain dalam keluarga, seperti saudara iklim keluarga dan gaya coping orangtua juga dapat memengaruhi coping style pada anak. Sedangkan, dalam penelitian ini aspek keluarga yang diteliti terbatas hanya pada orangtua. Pada penelitian ini, peneliti juga tidak meneliti bentuk aktivitas seperti apakah yang berkontribusi terhadap keterlibatan orangtua yang dipersepsikan oleh anak. Hal ini penting untuk diketahui sebagai masukan bagi orangtua dalam mengasuh anakanak mereka.

\section{DAFTAR PUSTAKA}

Affiani, L. (2016). Pengaruh Persepsi Keterlibatan Orangtua Terhadap Parenting Self-efficacy pada orangtua dengan anak usia kanak-kanak madya. Skripsi. Depok: Universitas Indonesia.

Barnes, S. K. (2011). An Investigation Into the Relationship Between Coping Strategies and Suicidal Ideation in a South African Sample of Male Adolescents (Doctoral dissertation, University of KwaZuluNatal, Pietermaritzburg).

Camara, M., Bacigalupe, G., \& Padilla, P. (2014). The role of social support in adolescents: are you helping me or stressing me out? International Journal of Adolescence and Youth.

Finley, G. E., \& Schwartz, S. J. (2004). The father involvement and nurturant fathering scales: Retrospective measures for adolescent and adult children. Educational and Psychological Measurement, 64(1), 143-164.

Finley, G. E., Mira, S. D., \& Schwartz, S. J. (2008). Perceived paternal and maternal involvement: Factor structures, mean differences, and parental roles. Fathering, 6(1), 62.

Frank, J. L., Bose, B., \& SchrobenhauserClonan, A. (2014). Effectiveness of a school-based yoga program on adolescent mental health, stress coping strategies, and attitudes toward violence: findings from a high-risk sample. Journal of applied school psychology, 30(1), 29-49.

Gelhaar, T., Seiffge-Krenke, I., Borge, A., Cicognani, E., Cunha, M., Loncaric, D., Macek, P., Steinhausen, H \& Metzke, C. W. (2007). Adolescent coping with everyday stressors: A seven-nation study of youth from central, eastern, southern, and northern Europe. European Journal of Developmental Psychology, 4(2), 129156.

Gonzalez-DeHass, A. R., Willems, P. P., \& Holbein, M. F. D. (2005). Examining 
the relationship between parental involvement and student motivation. Educational psychology review, 17(2), 99-123.

Gravetter, F. J., \& Forzano, L. B. (2012). Research methods for the behavioural science $4^{\text {th }} e d$. Canada: Wadsworth Cengage Learning.

Gravetter, F. J., \& Wallnau, L. B. (2013). Statistics for the behavioral science $9^{\text {th }}$ ed. Canada: Wadsworth Cengage Learning.

Han, Y. S., \& Jun, W. P. (2013). Parental involvement in child's development: Father vs. mother. Open Journal of Medical Psychology, 2(04), 1.

LaRue, D. E., \& Herrman, J. W. (2008). Adolescent stress through the eyes of high-risk teens. Pediatric nursing, 34(5), 375.

Lin, H. J., \& Yusoff, M. S. B. (2013). Psychological distress, sources of stress and coping strategy in high school students. International Medical Journal, 20(6), 672-676.

Persike, M., \& Seiffge-Krenke, I. (2012). Competence in coping with stress in adolescents from three regions of the world. Journal of youth and adolescence, 41(7), 863-879.

Seiffge-Krenke, I., \& Shulman, S. (1990). Coping style in adolescence: A crosscultural study. Journal of CrossCultural Psychology, 21(3), 351-377.

Seiffge-Krenke, I., Aunola, K., \& Nurmi, J. E., (2009). Changes in Stress Perception and Coping During Adolescence: The Role of Situational and Personal
Factors, Child Development, 80(1), 259 -279 .

Seiffge-Krenke, I., \& Pakalniskiene, V. (2011). Who shapes whom in the family: Reciprocal links between autonomy support in the family and parents' and adolescents' coping behaviors. Journal of Youth and Adolescence, 40(8), 983-995.

Shankar, N. L., \& Park, C. L. (2016). Effects of stress on students' physical and mental health and academic success. International Journal of School \& Educational Psychology, 4(1), 5-9.

Taufik, T., \& Ifdil, I. (2013). Kondisi Stres Akademik Siswa SMA Negeri di Kota Padang. Jurnal Konseling dan Pendidikan, 1(2), 143-150.

Verboom, C. E., Sijtsema, J. J., Verhulst, F. C., Pennix, B. W., \& Ormel, J. (2014) . Longitudinal associations between depressive problems, academic performance, and social functioning in adolescent boys and girls. Developmental Pscychology, 50(1), 247.

Wang, M., \& Sheikh-Khalil, S. (2014). Does Parental Involvement Matter for Student Achievement and Mental Health in High School?, Child Development, 85(2), 610-625.

Wong, M. M. (2008). Perceptios of parental involvement and autonomy support: Their relations with self-regulation, academic performance, substance use and resilience among adolescents. North American Journal, 10(3), 497-518.

Wrzesniewski, K., \& Chylinska, J. (2007). Assessment of Coping Styles and Strategies with School-Related Stress, 
School Psychology International, 28(2),

179-194. 
